\title{
Article
}

\section{Medication-taking after stroke: a qualitative meta-synthesis of the perspectives of stroke survivors, informal carers and health professionals}

Gibson, Josephine, Miller, Colette, Coupe, Jacqueline and Jones, Stephanie

Available at http://clok.uclan.ac.uk/28948/

Gibson, Josephine ORCID: 0000-0002-3051-1237, Miller, Colette ORCID: 00000003-0620-6029, Coupe, Jacqueline and Jones, Stephanie ORCID: 0000-00019149-8606 (2019) Medication-taking after stroke: a qualitative meta-synthesis of the perspectives of stroke survivors, informal carers and health professionals. Family Practice, 37 (1). pp. 4-14. ISSN 0263-2136

It is advisable to refer to the publisher's version if you intend to cite from the work. http://dx.doi.org/10.1093/fampra/cmz030

For more information about UCLan's research in this area go to http://www.uclan.ac.uk/researchgroups/ and search for < name of research Group>.

For information about Research generally at UCLan please go to http://www.uclan.ac.uk/research/

All outputs in CLoK are protected by Intellectual Property Rights law, including Copyright law. Copyright, IPR and Moral Rights for the works on this site are retained by the individual authors and/or other copyright owners. Terms and conditions for use of this material are defined in the policies page. 
Medication-taking after stroke: a qualitative meta-synthesis of the perspectives of stroke survivors, informal carers, and health professionals.

Running head: Medication-taking after stroke

Article category: systematic review

Josephine M.E. Gibson ${ }^{a}$; Colette Miller ; Jacqueline Coupe ${ }^{\mathrm{b}}$; Stephanie P. Jones ${ }^{\mathrm{a}}$

${ }^{a}$ School of Nursing, University of Central Lancashire, Preston, UK

${ }^{\mathrm{b}}$ Faculty of Health and Wellbeing, University of Central Lancashire, Preston, UK

Corresponding author: Dr JME Gibson, School of Nursing, Brook Building, Victoria Street, University of Central Lancashire, Preston PR1 2HE, UK. Email: jgibson4@uclan.ac.uk 


\section{Key messages}

- Medication adherence is often suboptimal after stroke.

- Interventions to improve medication adherence have limited effectiveness.

- The burden of 'medicines work' is substantial and multifaceted.

- It relies on trust between stroke survivors, carers and health professionals.

- Trust in the benefits of medicines themselves is also important. 


\begin{abstract}
Background

Lifelong secondary prevention medication is recommended after stroke or transient ischaemic attack. However, poor medication adherence and persistence, which lead to suboptimal health outcomes, are common, but the reasons for this are not well understood, mainly because there have been few studies reporting adherence barriers in stroke survivors.
\end{abstract}

\title{
Objective
}

The aim of this review was to undertake a meta-synthesis of qualitative studies of medication-taking after stroke. Outcomes of interest were: lived experiences, views and beliefs, and strategies and solutions used by community-dwelling stroke and TIA survivors, informal carers and healthcare professionals in relation to medication taking.

\section{Method}

The review protocol was registered on PROSPERO (CRD42018086792). A search of online bibliographic databases was performed using key search terms of stroke, persistence, adherence and medication for years 1980-2018. Citation tracking was also carried out. Studies using qualitative or mixed methods were included. Systematic data extraction and synthesis were conducted using a meta-ethnographic approach.

\section{Results}

Twelve studies were eligible for inclusion, with a total of 412 participants, two-thirds of whom were stroke survivors, ranging from 1 month to over 20 years post-stroke. Third-order themes identified were 'Medicines Work' - Information Work; Health Care Work; Carer Work; Emotional Work; Practical Work; and an underpinning theme of Trust. However, many studies had significant methodological weaknesses. 


\section{Conclusions}

This synthesis suggests that the burden of 'medicines work' after stroke is substantial and

multifaceted. Its successful undertaking depends on mutual trust between stroke survivors, carers and health care professionals, and trust in the benefits of medicines themselves.

\section{Key words}

Medication Adherence; Patient Experience; Qualitative Research; Secondary Prevention; Stroke; Systematic Review. 


\section{Background}

Survivors of stroke or transient ischaemic attack (TIA) need several long-term medications for optimum secondary prevention ${ }^{1}$ of recurrent stroke or other vascular disease (coronary artery and peripheral vascular disease), in addition to medication for any comorbidities. Adherence to secondary prevention medication reduces the risk of stroke recurrence by around $80 \%^{2}$. Poor poststroke medication adherence (MA) is, however, a common and clinically important problem ${ }^{3}$. Twothirds of stroke survivors need medication advice at 6-9 months ${ }^{4}$, less than half feel sufficiently informed about stroke prevention ${ }^{5}$, and many have other unmet needs in relation to medication management ${ }^{6}$. There is limited evidence for the effectiveness of interventions to improve secondary stroke prevention ${ }^{7}$, and although a number of national clinical guidelines for stroke include recommendations to support MA, these are mainly based on consensus ${ }^{1,8,9}$.

A better understanding of the barriers and enablers of MA could lead to the design of effective and feasible interventions which would have far-reaching effects on health ${ }^{10}$. Interventions which are not grounded in this way are likely to have limited effectiveness ${ }^{11}$. Research priorities for MA support (for any condition) include the evaluation of intervention strategies targeted to specific problems and subgroups ${ }^{12}$. However, people's experiences of the barriers and enablers of MA after stroke might be very different from those affecting the general population or those with other clinical conditions, because of such factors as the presence of residual physical or cognitive neurological disabilities. It may also be important to consider the presence of common comorbidities such as diabetes mellitus or coronary heart disease, and the additional medication needs imposed by these conditions. It is thus important to understand the perceptions and experiences of stroke survivors, informal carers, and health care professionals (HCPs) in relation to the barriers and enablers which may affect post-stroke MA, in order to provide appropriate support and to develop evidence-based interventions for future evaluation. Reviews have previously been undertaken of studies evaluating 
the effectiveness of interventions to support MA after stroke ${ }^{7}$, and of quantitative studies of predictors of MA after stroke ${ }^{13}$. Other reviews have synthesised the qualitative literature on related, non-stroke-specific topics such as people's beliefs and attitudes to taking statins ${ }^{14}$, patients' and carers' knowledge, attitudes and beliefs about medication adherence ${ }^{15}$, medication-related burden ${ }^{16}$, and medication taking in coronary artery disease ${ }^{17}$. However, there are no published syntheses of the qualitative literature exploring the views and experiences of stroke survivors, carers and HCPs on this topic.

The objective of this review was to undertake a qualitative meta-synthesis of the evidence base exploring the views and lived experiences of community-dwelling stroke and TIA survivors, informal carers and healthcare professionals in relation to medication taking after stroke.

\section{Methods}

\section{Search strategy}

An initial unpublished search of the literature, yielding 4 studies, was undertaken in 2013 and repeated for this review. The search strategy was developed from a scoping review and from the Cochrane Stroke Review Group short form search for stroke. Specific terms relating to secondary prevention, adherence, persistence, and medication were used to search relevant bibliographic databases (Medline, Biomed Central, CINAHL, AMED, EMBASE, psycINFO, British Nursing Index, Web of Science, NLM Gateway, PharmWeb and Bibliomap) for literature published from $1^{\text {st }}$ January 1980 to 18th January 2018. (See Supplementary file 1 for the full search strategy for Medline.) Forward and backward citation tracking was undertaken, including published systematic reviews relating to general medication taking, and reference lists of included articles. Key policy documents, websites and grey literature were also searched.

\section{Inclusion and exclusion criteria}


Development of the inclusion and exclusion criteria were informed by the initial scoping review, which suggested that available studies used a range of qualitative methodology, and often included the views and experiences of carers and HCPs as well as stroke survivors themselves. Articles were eligible for inclusion if they met the following criteria:

Population: Community dwelling stroke or TIA survivors, their informal carers (e.g. family members), and any primary or secondary care HCPs who prescribe, advise or otherwise support people in medication taking after TIA or stroke.

Exposure: Being prescribed, or being involved in the prescription, supply, or support in relation to, medication after TIA or stroke, for secondary prevention or any other co-morbidity.

Outcomes of interest: 1) Lived experiences of community-dwelling stroke and TIA survivors, informal carers and healthcare professionals in relation to medication taking after stroke. 2) Views and beliefs of community-dwelling stroke and TIA survivors, informal carers and healthcare professionals to barriers and facilitators of medication taking. 3) Strategies and solutions used by communitydwelling stroke and TIA survivors, informal carers and healthcare professionals to promote medication taking.

Eligible study designs included: qualitative studies; mixed method studies that reported some qualitative data relating to the outcomes of interest; studies including heterogeneous samples of people after stroke/TIA and those with non-stroke conditions if at least some stroke/TIA-specific primary and/or secondary data was reported.

Articles were ineligible for inclusion if they were: published only in abstract form; studies with no qualitative component; data related only to in-hospital or institutional medication taking; nonstroke/TIA population; not published in the English language, due to lack of resources for translation. Data screening and selection of studies 
Titles and abstracts were reviewed independently by pairs of reviewers against the inclusion/exclusion criteria. Full texts of potentially eligible studies were then retrieved and independently assessed by pairs of reviewers to identify the final studies for inclusion. Manual searching of the reference lists and citation tracking of included papers was conducted to identify any further potentially relevant studies. All qualitative studies that met the inclusion criteria were included regardless of epistemological underpinnings, as is common in the synthesis of health research ${ }^{18}$. Disagreements between reviewers were resolved through team discussions.

\section{Data Extraction}

Data were independently extracted by pairs of researchers using a bespoke data extraction form to ensure consistency. The form was initially tested on 3 studies and modified as necessary. Only data from the qualitative component of any mixed methods study, and only stroke-specific data from studies with heterogeneous stroke/non-stroke data, were included. Key information extracted from each of the primary studies included: bibliographic information; details of setting and location; population; research questions or aims, development of the interview schedule or other tools, data collection methods, data analysis methods, theoretical framework, and primary or secondary data relating to the outcomes of interest.

\section{Data Synthesis}

The meta-synthesis technique described by Noblit and Hare ${ }^{19}$ was used to synthesise the qualitative data, enabling collation and comparison of the evidence across the studies whilst preserving the meaning as interpreted by the original authors. First order constructs, as presented by the authors of the primary studies in the form of direct quotes from study participants were extracted and tabulated by authors 1-4. Second order constructs comprised interpretations, themes or statements developed by the primary studies' authors in response to the first order constructs. Common and contradictory themes were explored across the studies. Using an inductive approach, the review team then developed third order constructs after combining and exploring first and second order 
constructs to elicit an explanatory framework for the reported findings. At each stage of data synthesis, the team discussed and reached consensus on their interpretations.

The quality of the included studies was appraised using Walsh and Downe's criteria ${ }^{20}$. Pairs of researchers independently assessed each included study and then discussed their ratings to reach consensus. In addition to the published domains for data appraisal, we added an appraisal of the reporting of patient, carer and public involvement (PCPI) in the studies' design and conduct, because we felt that its increasing recognition as an essential component of high quality and ethically sound health care research warranted its inclusion. As is common practice in qualitative meta-synthesis, studies were included irrespective of their overall quality.

The research team included health services researchers with expertise in clinical nursing (authors 1 and 3) as well as expertise in systematic review (authors 2, 3, and 4). The first author also holds a prescribing qualification and has led (with author 3) a qualitative study exploring stroke unit nurses', stroke survivors' and carers' views and experiences of managing medication early after discharge.

This study was registered on PROSPERO (CRD42018086792) at https://www.crd.york.ac.uk/PROSPERO. The reporting of this qualitative evidence synthesis is in accordance with the Preferred Reporting Items for Systematic Reviews and Meta-Analyses $\left(\right.$ PRISMA) ${ }^{21}$ (see Supplementary file) and the ENTREQ reporting guidelines for qualitative synthesis ${ }^{22}$.

\section{Results}

Our search strategy initially yielded 971 articles. Following exclusion of duplicates, and screening of the title, abstract or complete article, 12 studies met the inclusion criteria. The PRISMA flowchart (Figure 1) illustrates the flow of studies through the synthesis. Table 1 summarises the included studies. 


\section{Study participants, design, and quality}

The twelve eligible studies included a total of 412 participants, of whom 271 (66\%) were stroke (246) or TIA (25) survivors, 106 (26\%) were carers and $33(8 \%)$ were HCPs or others; two were unknown. The time points of data collection were reported heterogeneously and ranged from 1 month to more than 20 years post-stroke.

There were nine qualitative studies $23,24,25,26,27,28,29,30,31$ and three studies utilising mixed methods ${ }^{32,33,34}$. Nine studies utilised purposive sampling $23,25,26,27,28,29,30,32,34$, and three utilised convenience sampling ${ }^{24,29,33}$; some aspects of sampling were poorly justified. Methods included semi-structured interviews ${ }^{24,25,26,27,29,31,32,33}$; semi-structured interviews and focus groups ${ }^{23,34}$, and analysis of on-line 'chat room' discussions ${ }^{28,30}$.

Nine studies were assessed as being of moderate quality and three studies were assessed as being of weak quality. Common limitations in the studies included lack of an appropriate theoretical framework, absent key participant data (e.g. age, time since stroke), lack of data saturation, absent participant validation, ethical concerns, and failure to report or consider divergent views. Indeed, one study ${ }^{24}$ excluded the views of one interviewee (the only male participant) because his views were divergent. In most studies the professional background of the researchers was not explicitly reported, and the identity of the member or members of the research team who conducted the data collection was unclear, which limited considerations of reflexivity in this synthesis. Only two studies reported any PCPI activities, namely a formal PCPI group ${ }^{23}$ and the incorporation of stroke survivor feedback about the interview schedule ${ }^{27}$. 
Each study was conducted in a single country, including the UK $23,26,27,28,29,30,31,32,33$, USA $^{24}$, France ${ }^{25}$ and Ghana ${ }^{34}$, the latter being the only low or middle income country (LMIC) represented. Participants included stroke survivors only $29,31,32,33$; stroke survivors and carers ${ }^{23,26,28,30}$; stroke survivors, carers and healthcare professionals ${ }^{25,27}$; stroke survivors, carers, community leaders and healthcare providers $^{34}$, and carers only ${ }^{24}$. Where demographic information for stroke survivors was reported $^{23,25,27,28,29,30,31,32,33}$ the mean age was 63.1 years (range 17-93); with $45 \%$ being female. Only one study ${ }^{25}$ reported carers' ages (mean 60 years, range 40-78). Four studies reported participants' ethnicities $24,29,31,33$, of which only one ${ }^{24}$ reported the inclusion of participants of non-white ethnicities.

\section{Themes identified}

Two overall third order themes: Doing Medicines Work, and Trust, were developed from the firstand second-order themes reported. Doing Medicines Work encompassed several types of work; Information work; Healthcare work; Carer work; Emotional work and Practical work, all of which were underpinned by Trust in HCPs, others, or in the medicines themselves. These themes are represented schematically in Figure 2.

A synopsis of each theme is provided below, and exemplar first-order quotes for each theme and sub-theme are given in Table 2.

1. Information work. This subtheme includes all the work that stroke survivors do to obtain, understand and evaluate information about their medicines, such as the reason for the drug or drugs, the underpinning pharmacological and evidence base, and knowledge about how to take it. Positive examples of information work included HCPs taking time to explain the medication, the provision of written information by HCPs and their responsiveness to questions. However, many stroke survivors and carers reported a lack of information provision and of discourse around medications. Preferences for written or verbal information varied. There was also a need for ongoing 
information, especially when medication brands were changed. Stroke survivors relied on visual cues about their medication, such as its colour, shape or packaging, but HCPs did not volunteer information about this which led to confusion and further information seeking by the stroke survivor.

2. Healthcare work. This subtheme includes the work that stroke survivors undertake to engage with health care services in order to obtain their medicines, arrange and attend monitoring and medicines review. It also includes the reciprocal work performed by HCPs and the interactions between stroke survivors and HCPs. Negative aspects of healthcare work included dislike of the need for monitoring such as blood tests for vitamin K antagonists (warfarin), and the 'kerfuffle' of arranging medical review appointments, which were seen as a scarce resource. This could lead to a total lack of ongoing medication support, as with the stroke survivor who had not seen their GP in the 14 months since their stroke. Even when ongoing healthcare advice was obtained it might have perceived negative consequences such as an additional medication being prescribed. However, there were some examples of stroke survivor-centred healthcare work where HCPs were responsive to stroke survivors' and carers' concerns and difficulties with medication.

3. Carer work. This subtheme includes the work that informal carers (family members, friends or neighbours) perform to assist the stroke survivor with any other type of medicines work. The importance of carer work was referred to by stroke survivors and HCPs as well as carers themselves. Many examples entailed organising the medication, whereby carers took responsibility for obtaining medication supplies and establishing a system for the stroke survivor to be able to independently take their medication, but this could lead to errors if the carer was then not available. Carer work could also include overseeing medication-taking where direct supervision was felt to be needed, and facilitating access to HCP support. Interactions between stroke survivors and carers about the 
medication also fell under this theme, and often included conflicts between the stroke survivor and carer.

4. Emotional work. This subtheme includes the motivational work that stroke survivors and carers perform in relation to long-term medication taking. The perceived necessity for taking medication was framed in terms of fear of having another stroke, which was felt to have serious or potentially even fatal consequences. HCPs also recognised that MA was contingent on the stroke survivor understanding the risk of stroke recurrence. Some stroke survivors were unconcerned about missing medications occasionally. They also expressed concerns about taking medication, including a dislike of taking medication, particularly multiple medications, not being 'back to normal', stigma and embarrassment, and worries about potential physical harm such as side effects. Very few HCPs mentioned this emotional work that stroke survivors performed; one HCP even took a protective stance by suggesting that HCPs tended to avoid talking about the necessity for medication with stroke survivors as they were 'already anxious'.

5. Practical work. This subtheme includes a range of direct and indirect activity which is necessary for the stroke survivor to take their medication. It included logistical and technical work, including organising, storing, and keeping track of doses taken as well as the act of self-administering the medication. It also included dealing with difficulties caused by physical or cognitive sequelae of stroke that affected medication-taking. Successful medication adherence entailed work to evolve and maintain a routine. This often relied on interaction with other people, notably carers, and strategies and solutions to maintain routines when a change of circumstances threatened to derail medicines taking. Enablers of practical work included the stability of the medication regime and of the stroke survivor's daily routine; barriers included the need to modify the routine and the complexity of the regime. Affordability of medication for stroke survivors was a concern in two non- 
UK studies, although one UK study also discussed the impact of cost-saving measures within the National Health Service on the availability of specific brands of medication.

6. Trust. This theme encapsulates the trust that stroke survivors and carers have to develop in the efficacy of the medication in terms of its potential benefits. Trust could be hampered by the imperceptible benefit conferred by medications for stroke prevention, whereby efficacy could ultimately be evaluated only by the continued non-recurrence of stroke. The concomitant reduction in risk of coronary artery or peripheral vascular disease was not noted by any participants. However, some participants expressed different degrees of trust in the efficacy of specific medication. Where they readily understood the mechanism of action, or they had evidence from a surrogate endpoint such as blood pressure reduction, this contributed to their trust in the efficacy of that medication. Medicine-taking was also mediated by beliefs about healthcare, including trust, or lack of it, in individual practitioners and in the healthcare system as a whole. Notably in the one study conducted in a LMIC, there was a lack of trust in modern medicines.

\section{Conclusions}

This qualitative synthesis has identified the various types of medicines work reported in the literature that are performed by stroke survivors, carers and HCPs in order to establish and maintain a medication regime after stroke. This complex medicines work and the underpinning need to develop trust are likely to constitute a substantial treatment burden, regardless of the severity of the stroke.

There are some areas of this body of literature where high quality evidence is particularly scarce. These include the views of carers, even though 7 of the 12 included studies recruited at least some carers, which is noteworthy given the increasing recognition of the value of carer support in many 
aspects of life after stroke and in MA generally. Data about the impact of the physical and cognitive sequelae of stroke on people's medication adherence are also scant. It is unclear whether this represents absence of problems in the population studied, given that they may have been younger and less disabled by their stroke than the general stroke population, or is due to the studies' designs and content.

Our comprehensive search strategy enables us to suggest with confidence that we have included most studies published in English up to January 2018. As with any review, publication bias may have influenced the results ${ }^{37}$. We limited the search to studies published in English, and 10 of the 12 studies were from Anglophone countries, with only one being conducted in a LMIC, and with each included study being conducted in a single country. Some of the issues identified (e.g. access to and cost of medications) may be highly context-dependent due to international variations in the organisation and funding of health care, especially given the preponderance of studies from the UK and the scarcity of studies from LMICs.

Given the complexity of 'medicines work' and the inherent resistance to taking medicines after stroke that is highlighted by this review, it is perhaps not surprising that it has thus far proved difficult to design interventions that are effective in improving MA and clinical outcomes ${ }^{7}$. Such interventions would need to take account of diverse and unique sets of predictors of and barriers to MA which affect different stroke survivors in order to be effective. Although some of these barriers have been identified in observational studies ${ }^{13}$, it is not clear who is most at risk of poor MA, nor what types of interventions are most suited to which individuals. This individualisation of medicines support is not easily captured in a study protocol, practice guideline or manual. Furthermore, the importance of trust as a keystone to MA after stroke underpins the role of the individual stroke survivor/health professional partnership in the provision of tailored support. While it may be a relatively simple task to identify, and formulate a plan to overcome, some barriers to MA after 
stroke (for example, problems with manual dexterity), it is perhaps more difficult to identify and address the complex issues of trust which underlie much intentional non-adherence, particularly as stroke survivors may not wish to jeopardise their working relationship with HCPs by expressing lack of trust in their treatment. The importance of this partnership may also underlie some of the problems with the implementation of potentially useful interventions into everyday practice, because the stroke survivors who have participated in clinical trials and the development of interventions are not necessarily representative of the wider populations of interest in terms of their beliefs about, and trust in, health care interventions.

Our categories of 'medicines work' align to some extent with previously described elements of treatment burden in stroke ${ }^{26}$. The need for trust in MA after stroke also aligns with the concepts of necessity and concerns which underpin much thinking around medication adherence ${ }^{35}$. Trust in medicines will be present when the individual's perception of their necessity outweighs any concerns they may have. It may be highly context-dependent, as illustrated by the presence of trust in traditional healers and lack of trust in 'western' medicine described in one included study ${ }^{34}$. The lack of trust in medicines after stroke also concurs with findings from a synthesis of medicine-taking across all health conditions that people are reluctant to take medicines and generally prefer to take as few as possible ${ }^{36}$. Some of the findings of other recent relevant reviews also resonate with the themes presented here. In studies of people's beliefs and attitudes to taking statins ${ }^{14}$, trust in the efficacy of the medication and in HCPs were important, and in studies of medication taking in coronary artery disease ${ }^{17}$, working relationships with prescribing clinicians were critical. Across all health care conditions, a general review of patients' and carers' knowledge, attitudes and beliefs about medication adherence ${ }^{15}$ found that beliefs about medications, family support, and the role of HCPs were important, and a review of medication-related burden ${ }^{16}$ suggested that patients' lived experiences of medicines and associated treatment burden needed to be appreciated by HCPs. 
This review of specific barriers, facilitators and predictors of medication persistence and adherence post-stroke has identified many gaps and quality issues in the literature. Of particular note, there are few studies which covered the period early after stroke when people are adjusting to their diagnosis and their new or altered medication regime. The available literature focuses almost entirely on the experiences of stroke survivors in countries in the global North, with only one study conducted in a LMIC and only one further study reporting the inclusion of any non-caucasian participants. Although carers and HCPs constituted $26 \%$ and $8 \%$ respectively of the participants across all 12 studies, the experiences of carers, in particular, were only reported superficially. The sole study which focused only on carers was assessed as poor quality. Further high-quality studies on this topic should endeavour to address these gaps in the literature.

Many of the issues discussed here are not necessarily specific to stroke, and might also apply to people taking long-term medication for many conditions. Whilst it is important to address conditionspecific issues it may also be fruitful to carefully consider the relevance of the findings of similar studies in other conditions and populations, such as cardiovascular primary prevention, secondary prevention in coronary artery disease and peripheral vascular disease, multimorbidity, and polypharmacy, when designing future research studies and interventions. As a corollary, researchers and practitioners in these other fields may wish to address some of the issues identified in this review.

This synthesis illustrates strongly that the burden of medicines work after stroke is substantial and multifaceted, and depends on mutual trust between stroke survivors, carers and HCPs, as well as trust in the benefits of medicines themselves. To better support stroke survivors, HCPs working with stroke survivors need to consider ways in which they can support clear information exchange, minimise the work for patients in accessing medication support from the health care system, help carers to be engaged in supporting the stroke survivor, address people's beliefs and concerns about 
their medication and the risk of recurrent stroke, and develop individualised strategies to address practical problems experienced by stroke survivors in relation to taking medication.

\section{Declarations}

Ethics: No ethical review was required for this work.

\section{Sources of funding}

Initial scoping work was funded by the Undergraduate Research Internship Scheme from the Centre for Research-Informed Teaching, University of Central Lancashire, UK, awarded to JG, and held by CM.

JG and CM are partly funded by the National Institute for Health Research Collaboration for Leadership in Applied Health Research and Care North West Coast. The views expressed are those of the authors and not necessarily those of the NIHR, NHS or Department of Health and Social Care.

\section{Conflicts of interest}

The authors declare that they have no conflicts of interest. 


\section{References}

1. Intercollegiate Stroke Working Party. National Clinical Guidelines for Stroke (5th Edition). London; RCP, 2016

2. Hackam DG, Spence JD. Combining multiple approaches for the secondary prevention of vascular events after stroke: a quantitative modeling study. Stroke 2007; 38: 1881-1885.

3. Lummis HL, Sketris IS, Gubitz GJ et al. Medication persistence rates and factors associated with persistence in patients following stroke: a cohort study. BMC Neurol; 2008. 10;8:25.

4. Martin BJ, Yip B, Hearty M et al. Outcome, functional recovery and unmet needs following acute stroke. Scott Med J. 2002; 47(6):136-7

5. National Audit Office. Progress in Improving Stroke Care. London; The Stationery Office. 2010

6. French B, Leathley M, Radford K et al. UK Stroke Survivor Needs Survey: Information Mapping Exercise. London, The Stroke Association, 2008.

7. Bridgwood B, Lager KE, Mistri AK, Khunti K, Wilson AD, Modi P. Interventions for improving modifiable risk factor control in the secondary prevention of stroke. Cochrane Database of Systematic Reviews; 2018. Issue 5. Art. No.: CD009103. DOI: 10.1002/14651858.CD009103.pub3.

8. National Stroke Foundation. Clinical Guidelines for Stroke Management. Melbourne, Australia, National Stroke Foundation. 2010.

9. Kernan WN, Ovbiagele B, Black HR. et al. Guidelines for the prevention of stroke in patients with stroke and transient ischemic attack. A guideline for healthcare professionals from the American Heart Association/American Stroke Association. Stroke; 2014. 45:00-00.

10. Haynes RB, McDonald H, Garg AX, Montague P. Interventions for helping patients to follow prescriptions for medications. The Cochrane Database of Systematic Reviews; 2002. Issue 2. Art. No.: CD000011. DOI: 10.1002/14651858.CD000011. 
11. Nieuwlaat R, Wilczynski N, Navarro T et al. Interventions for enhancing medication adherence. Cochrane Database of Systematic Reviews; 2014. Issue 11. Art. No.: CD000011. DOI: 10.1002/14651858.CD000011.pub4.

12. Nunes V, Neilson J, O'Flynn N, et al . Clinical Guidelines and Evidence Review for Medicines Adherence: involving patients in decisions about prescribed medicines and supporting adherence. London: National Collaborating Centre for Primary Care and Royal College of General Practitioners; 2009.

13. AlShaikh, S. A., Quinn, T., Dunn, W., Walters, M., \& Dawson, J. Predictive factors of nonadherence to secondary preventative medication after stroke or transient ischaemic attack: A systematic review and meta-analyses. European Stroke Journal; 2016. 1(2), 65-75. https://doi.org/10.1177/2396987316647187

14. Ju A, Hanson CS, Banks E, Korda R, Craig JC, Usherwood T, MacDonald P, Tong A. Patient beliefs and attitudes to taking statins: systematic review of qualitative studies. Br J Gen Pract; 2018. 68 (671): e408-e419. DOI: https://doi.org/10.3399/bjgp18X696365

15. Kelly M, McCarthy S, Sahm L . Knowledge, attitudes and beliefs of patients and carers regarding medication adherence: a review of qualitative literature. European Journal of Clinical Pharmacology; 2014. 70, (12) 1423-1431

16. Mohammed MA, Moles RJ, Chen TF Medication-related burden and patients' lived experience with medicine: a systematic review and metasynthesis of qualitative studies. BMJ Open; 2016. 6:e010035. doi: 10.1136/bmjopen-2015-010035

17. Rashid MA, Edwards D, Walter FM, Mant J. Medication Taking in Coronary Artery Disease: A Systematic Review and Qualitative Synthesis. Ann Fam Med; 2014. 224-232. doi: 10.1370/afm.1620 
18. Booth A. Searching for qualitative research for inclusion in systematic reviews: a structured methodological review. Systematic Reviews; 2016. 5:74

19. Noblit GW and Hare RD. Meta-ethnography: Synthesizing qualitative studies. London, England. SAGE, 1988.

20. Walsh D and Downe S. Appraising the quality of qualitative research. Midwifery; 2006. 22 108-119.

21. Moher D, Liberati A, Tetzlaff J et al. Preferred reporting items for systematic reviews and meta-analyses: The PRISMA statement. Ann Intern Med; 2009.15(4):264-269.

22. Tong A, Flemming K, Mclnnes E, Oliver S, Craig J. Enhancing transparency in reporting the synthesis of qualitative research: ENTREQ. BMC Medical Research Methodology; 2012. 12:181 https://doi.org/10.1186/1471-2288-12-181

23. Allison R, Evans PH, Kilbride C, Campbell JL. Secondary prevention of stroke: using the experiences of patients and carers to inform the development of an educational resource. Family Practice; 2008. Oct;25(5):355-61.

24. Bakas T, Austin JK, Okonkwo KF, Lewis RR, Chadwick L. Needs, concerns, strategies, and advice of stroke caregivers the first 6 months after discharge. J Neurosci Nurs; 2002. Oct;34(5):242-51.

25. Bauler S, Jacquin-Courtois S, Haesebaert J, Luaute J, Coudeyre E, Feutrier C, Allenet B, Decullier E, Rode G, Janoly-Dumenil A. Barriers and facilitators for medication adherence in stroke patients: a qualitative study conducted in French neurological rehabilitation units. European Neurology; 2014. 72:262-270 D OI: 10.1159/000362718.

26. Gallacher K, May CR, Langhorne P, Mair FS. A conceptual model of treatment burden and patient capacity in stroke. BMC Family Practice; 2018. 19:9 DOI 10.1186/s12875-017-06914. 
27. Jamison J, Graffy J, Mullis R, Mant J, Sutton S. Barriers to medication adherence for the secondary prevention of stroke: a qualitative interview study in primary care. Br J Gen Pract; 2016. DOI: 10.3399/bjgp16X685609

28. Jamison J, Sutton S, Mant J, de Simoni A. Barriers and facilitators to adherence to secondary stroke prevention medications after stroke: analysis of survivors and caregivers views from an online stroke forum. BMJ Open; 2017. 7:e016814. doi:10.1136/ bmjopen2017-016814

29. Kelly J. D'Cruz G, Wright D. Patients with dysphagia: Experiences of taking medication. Journal of Advanced Nursing; 2010. 66(1), 82-91.

30. Izuka NJ, Alexander MAW Balasooriya-Smeekens C, Mant J, De Simoni A. How do stroke survivors and their carers use practitioners' advice on secondary prevention medications? Qualitative study of an online forum. Family Practice; 2017. Vol. 34, No. 5, 612-620 doi:10.1093/fampra/cmx023

31. Souter C, Kinnear A, Kinnear M, Mead G. Optimisation of secondary prevention of stroke: a qualitative study of patients' beliefs, concerns and difficulties with their medicines International Journal of Pharmacy Practice; 2014. 22, pp. 424-432.

32. Chambers JA, O'Carroll RE, Hamilton B. et al. Adherence to medication in stroke survivors: A qualitative comparison of low and high adherers. British Journal of Health Psychology; 2011. 16(3), 592-609.

33. Chambers JA, O'Carroll RE, Dennis M, Sudlow C, Johnston M. "My doctor has changed my pills without telling me": impact of generic medication switches in stroke survivors. J Behav Med; 2014. 37:890-901 DOI 10.1007/s10865-013-9550-5

34. Nichols M, Stephen SF, Singh A, Qanungo S, Treiber F, Ovbiagele B, Saulson R, Patel S, Jenkins C. Assessing Mobile Health Capacity and Task Shifting Strategies to Improve Hypertension Among Ghanaian Stroke Survivors. Am J Med Sci; 2017. December 354(6): 573-580. doi:10.1016/j.amjms.2017.08.005 
35. Horne, R., Chapman, S. C., Parham, R., Freemantle, N., Forbes, A., \& Cooper, V. Understanding patients' adherence-related beliefs about medicines prescribed for longterm conditions: a meta-analytic review of the Necessity-Concerns Framework. PloS One; 2013. 8(12), e80633. doi:10.1371/journal.pone.0080633

36. Pound P, Britten N, Morgan M, Yardley L, Pope C, Daker-White G, Campbell R. Resisting medicines: a synthesis of qualitative studies of medicine taking. Social Science \& Medicine; 2005. 61 (1) 133-155.

Figure 1: Flow chart illustrating the literature search for qualitative meta-synthesis of medicationtaking after stroke.

Figure 2. Themes identified in qualitative meta-synthesis of studies of medication-taking after stroke. 
Table 1: Summary of studies in qualitative synthesis of medication-taking after stroke, 1980-2018.

\begin{tabular}{|c|c|c|c|c|c|c|c|}
\hline $\begin{array}{l}\text { First Author, } \\
\text { Year and } \\
\text { Country }\end{array}$ & Participants & $\begin{array}{l}\text { Time } \\
\text { point }\end{array}$ & Sampling & $\begin{array}{l}\text { Data } \\
\text { Collection } \\
\text { Methods }\end{array}$ & $\begin{array}{l}\text { Mean Age } \\
\text { (range) }\end{array}$ & $\begin{array}{l}\text { Female } \\
(\%)\end{array}$ & Topic \\
\hline $\begin{array}{l}\text { Allison, 2008, } \\
\text { UK }\end{array}$ & $\begin{array}{l}38 \text { ( } 25 \text { stroke } \\
\text { survivors and } 13 \text { care } \\
\text { givers) }\end{array}$ & $\begin{array}{l}3 \text { to } 24 \\
\text { months } \\
\text { post } \\
\text { stroke }\end{array}$ & Purposive & $\begin{array}{l}25 \text { face-to- } \\
\text { face } \\
\text { interviews } \\
\text { and } 4 \text { focus } \\
\text { groups }\end{array}$ & $\begin{array}{l}69.5(37-91) \\
\text { stroke } \\
\text { survivors }\end{array}$ & $\begin{array}{l}44 \% \\
\text { stroke } \\
\text { survivors; } \\
62 \% \text { care } \\
\text { givers }\end{array}$ & $\begin{array}{l}\text { Knowledge of risk of hypertension; experiences of } \\
\text { receiving information; feedback on the educational } \\
\text { resource provided; testing utility of the resource }\end{array}$ \\
\hline $\begin{array}{l}\text { Bakas, 2002, } \\
\text { USA }\end{array}$ & $\begin{array}{l}14 \text { stroke family care } \\
\text { givers }\end{array}$ & $\begin{array}{l}\text { Within } 6 \\
\text { months } \\
\text { post } \\
\text { discharge }\end{array}$ & Convenience & $\begin{array}{l}13 \text { telephone } \\
\text { interviews; } 1 \\
\text { face-to-face } \\
\text { interview }\end{array}$ & NS & $\begin{array}{l}100 \% \\
\text { care } \\
\text { givers }\end{array}$ & $\begin{array}{l}5 \text { questions: } 1 \text {. What is a typical day providing care for a } \\
\text { stroke survivor? } 2 \text {. Do you have any concerns or } \\
\text { problems since the stroke survivor has returned home? } \\
3 \text {. What have you found helpful in terms of dealing with } \\
\text { concerns or problems? } 4 \text {. What advice would you give } \\
\text { someone else in the same situation? } 5 \text {. If we were to } \\
\text { develop a programme to help care givers what would be } \\
\text { most helpful? }\end{array}$ \\
\hline $\begin{array}{l}\text { Bauler, 2012, } \\
\text { France }\end{array}$ & $\begin{array}{l}26 \text { ( } 8 \text { stroke } \\
\text { survivors, } 6 \text { care } \\
\text { givers, } 4 \text { physicians, } 8 \\
\text { nurses) in outpatient } \\
\text { and inpatient rehab } \\
\text { units }\end{array}$ & $\begin{array}{l}1 \text { month } \\
\text { to more } \\
\text { than } 10 \\
\text { years }\end{array}$ & Purposive & $\begin{array}{l}\text { Face-to-face } \\
\text { interviews }\end{array}$ & $\begin{array}{l}53.4 \text { (38 to } 67 \text { ) } \\
\text { stroke } \\
\text { survivors; } 60 \\
\text { ( } 40 \text { to } 78 \text { ) care } \\
\text { givers; } 28 \text { ( } 23 \\
\text { to } 35 \text { ) health } \\
\text { professionals }\end{array}$ & $\begin{array}{l}5(36 \%) \\
\text { stroke } \\
\text { survivors; } \\
9(74 \%) \\
\text { Health } \\
\text { professio } \\
\text { nals }\end{array}$ & $\begin{array}{l}\text { Stroke beliefs, medication issues, patient experience and } \\
\text { relationships with healthcare professionals }\end{array}$ \\
\hline $\begin{array}{l}\text { Chambers, } \\
\text { 2011, UK }\end{array}$ & $\begin{array}{l}26 \text { (13 low adhering } \\
\text { and } 13 \text { high adhering) } \\
\text { ischaemic stroke } \\
\text { survivors living } \\
\text { independently }\end{array}$ & $\begin{array}{l}\text { Within } 15 \\
\text { months } \\
\text { post } \\
\text { stroke }\end{array}$ & Purposive & $\begin{array}{l}\text { Face-to-face } \\
\text { interviews }\end{array}$ & $\begin{array}{l}63.5 \text { (NS) } \\
\text { stroke } \\
\text { survivors }\end{array}$ & $\begin{array}{l}46 \% \\
\text { stroke } \\
\text { survivors }\end{array}$ & $\begin{array}{l}\text { Experience of taking medication and beliefs about } \\
\text { medication }\end{array}$ \\
\hline
\end{tabular}




\begin{tabular}{|c|c|c|c|c|c|c|c|}
\hline $\begin{array}{l}\text { Chambers, } \\
\text { 2014, UK }\end{array}$ & $\begin{array}{l}28 \text { stroke and TIA } \\
\text { stroke survivors living } \\
\text { in the community }\end{array}$ & $\begin{array}{l}\text { Three } \\
\text { months } \\
\text { to } 6.5 \\
\text { months } \\
\text { post } \\
\text { discharge }\end{array}$ & Convenience & $\begin{array}{l}\text { Face-to-face } \\
\text { interviews }\end{array}$ & 68.3 (51 to 85 ) & $\begin{array}{l}39 \% \\
\text { stroke } \\
\text { survivors }\end{array}$ & $\begin{array}{l}\text { Aspects of the medication which may change as a result } \\
\text { of a switch to another brand of medication; stroke } \\
\text { survivors understanding of generic medication and the } \\
\text { reasons behind medication switches; the impact } \\
\text { medication switches had on stroke survivors medication } \\
\text { taking }\end{array}$ \\
\hline $\begin{array}{l}\text { Gallacher, } \\
\text { 2018, UK }\end{array}$ & $\begin{array}{l}29 \text { stroke survivors } \\
\text { living in the } \\
\text { community and an } \\
\text { unspecified number } \\
\text { of their carers }\end{array}$ & $\begin{array}{l}\text { 2-241 } \\
\text { months, } \\
\text { mean } \\
68.3 \\
\text { months. }\end{array}$ & $\begin{array}{l}\text { Purposive; } \\
\text { from both } \\
\text { hospital OPD } \\
\text { and GPs }\end{array}$ & $\begin{array}{l}\text { Face-to-face } \\
\text { interviews }\end{array}$ & $\begin{array}{l}\text { Stroke } \\
\text { survivors - } \\
\text { Mean } 68 \text { years } \\
\text { (range } 40-49 \\
\text { to } 80-89, \text { exact } \\
\text { ages not } \\
\text { given) }\end{array}$ & $44.8 \%$ & $\begin{array}{l}\text { Treatment burden after stroke } \\
\text { Factors affecting capacity to cope with treatment burden }\end{array}$ \\
\hline $\begin{array}{l}\text { Jamison, } \\
\text { 2016, UK }\end{array}$ & $\begin{array}{l}28 \text { stroke survivors, } \\
14 \text { accompanying } \\
\text { caregivers, } 5 \text { GPs }\end{array}$ & $\begin{array}{l}4 \text { months } \\
\text { to } 18 \\
\text { years; } \\
\text { mean } 5.7 \\
\text { years }\end{array}$ & Purposive & $\begin{array}{l}\text { Face-to-face } \\
\text { interviews }\end{array}$ & $\begin{array}{l}74.0 \text { (61 to 93) } \\
\text { stroke } \\
\text { survivors }\end{array}$ & $\begin{array}{l}25 \% \\
\text { stroke } \\
\text { survivors }\end{array}$ & $\begin{array}{l}\text { Patient } \\
\text { Health and medication since stroke; medication taking. } \\
\text { Caregiver } \\
\text { Role in managing patient's medication; barriers and } \\
\text { concerns; strategies to improve medication taking. } \\
\text { GP } \\
\text { Treatment for secondary prevention of stroke; strategies } \\
\text { to improve medication taking; patient understanding and } \\
\text { management; limitations of current regimens for } \\
\text { secondary prevention }\end{array}$ \\
\hline $\begin{array}{l}\text { Jamison 2017, } \\
\text { UK }\end{array}$ & $\begin{array}{l}84 \text { ( } 49 \text { stroke } \\
\text { survivors; } 33 \text { care } \\
\text { givers; } 2 \text { not known) }\end{array}$ & $\begin{array}{l}37(44 \%) \\
(0-12 \\
\text { months); } \\
25(30 \%) \\
(1-5 \\
\text { years); } 4 \\
(5 \%)(6- \\
10 \text { years); } \\
2(2 \%)\end{array}$ & Purposive & $\begin{array}{l}\text { Analysis of } \\
\text { on-line } \\
\text { discussion } \\
\text { posts }\end{array}$ & $\begin{array}{l}58(32-91) \\
\text { stroke } \\
\text { survivors }\end{array}$ & $\begin{array}{l}\text { (45\%) } \\
\text { female; } \\
7 \% \\
\text { unknown }\end{array}$ & $\begin{array}{l}\text { The PAPA framework including: (beliefs and preferences) } \\
\text { and practical (capability and resources) factors which } \\
\text { have an influence on stroke survivors commencing and } \\
\text { continuing treatment. Barriers and facilitators of } \\
\text { adherence to secondary prevention medications }\end{array}$ \\
\hline
\end{tabular}




\begin{tabular}{|c|c|c|c|c|c|c|c|}
\hline & & $\begin{array}{l}\text { (11 and } \\
15 \text { years); } \\
1(1 \%)(15 \\
\text { years }+) ; \\
15(18 \%) \\
\text { unknown }\end{array}$ & & & & & \\
\hline $\begin{array}{l}\text { Kelly, 2011, } \\
\text { UK }\end{array}$ & $\begin{array}{l}11 \text { people with } \\
\text { dysphagia living } \\
\text { independently }>60 \\
\text { years ( } 2,18 \% \text { stroke } \\
\text { survivors) }\end{array}$ & NS & Convenience & $\begin{array}{l}\text { Face-to-face } \\
\text { interviews }\end{array}$ & NS & $0 \%$ & $\begin{array}{l}\text { Medication formulation; information exchange; factors } \\
\text { affecting medication adherence; strategies used for } \\
\text { swallowing medication }\end{array}$ \\
\hline $\begin{array}{l}\text { Izuka, 2017, } \\
\text { UK }\end{array}$ & $\begin{array}{l}50 \text { ( } 33 \text { stroke } \\
\text { survivors, } 17 \text { care } \\
\text { givers) }\end{array}$ & $\begin{array}{l}\text { Mean } 2.3 \\
\text { years }\end{array}$ & Purposive & $\begin{array}{l}\text { Analysis of } \\
\text { on-line } \\
\text { discussion } \\
\text { posts }\end{array}$ & $\begin{array}{l}49.0(17-88) \\
\text { stroke } \\
\text { survivors }\end{array}$ & $\begin{array}{l}54 \% \\
\text { stroke } \\
\text { survivors }\end{array}$ & Participants engaged in free discussion about any topic. \\
\hline $\begin{array}{l}\text { Nichols, 2017, } \\
\text { Ghana }\end{array}$ & $\begin{array}{l}38 \text { (13 stroke } \\
\text { survivors, } 9 \\
\text { caregivers, } 6 \text { faith- } \\
\text { based community } \\
\text { leaders. Interviews: } \\
10 \text { healthcare } \\
\text { providers and } \\
\text { hospital } \\
\text { administrators) }\end{array}$ & $\begin{array}{l}8 \text { less } \\
\text { than } 1 \\
\text { year and } \\
5 \text { over } 1 \\
\text { year post } \\
\text { stroke }\end{array}$ & Purposive & $\begin{array}{l}\text { Focus groups } \\
\text { and face-to- } \\
\text { face } \\
\text { interviews }\end{array}$ & $\begin{array}{l}55.3 \text { (NS) } \\
\text { Overall group }\end{array}$ & $\begin{array}{l}64 \% \\
\text { Overall } \\
\text { group }\end{array}$ & $\begin{array}{l}\text { Focus groups: (1) beliefs about HTN and stroke risk factor } \\
\text { control, (2) existing self-management strategies and } \\
\text { experiences, (3) expectations and preferences, (4) } \\
\text { knowledge and (5) impressions of nurse navigators and } \\
\text { remote monitoring or mHealth technology. } \\
\text { Interviews: (1) current approaches to HTN treatment and } \\
\text { stroke risk factor control, (2) perceived gaps in care, (3) } \\
\text { cultural competence or communication, (4) knowledge } \\
\text { of treatment guidelines, (5) impressions of in-hospital } \\
\text { health education, involvement of nurse navigators and } \\
\text { home BP monitoring }\end{array}$ \\
\hline $\begin{array}{l}\text { Souter, 2014, } \\
\text { UK }\end{array}$ & $\begin{array}{l}30 \text { stroke survivors } \\
\text { with ischaemic or } \\
\text { haemorrhagic stroke } \\
\text { from acute stroke, } \\
\text { rehabilitation or } \\
\text { outpatient settings }\end{array}$ & $\begin{array}{l}\text { Within } 12 \\
\text { months of } \\
\text { stroke } \\
\text { onset }\end{array}$ & Purposive & $\begin{array}{l}\text { Face-to-face } \\
\text { interviews }\end{array}$ & $\begin{array}{l}69(32-86) \\
\text { stroke } \\
\text { survivors }\end{array}$ & $\begin{array}{l}50 \% \\
\text { stroke } \\
\text { survivors }\end{array}$ & $\begin{array}{l}\text { Questions in relation to condition (stroke); questions in } \\
\text { relation to medicines; side effects or worries about } \\
\text { medicines; inconvenience/ effects on lifestyle; } \\
\text { information provision; support }\end{array}$ \\
\hline
\end{tabular}


Table 2: Exemplar first-order quotes from a qualitative synthesis of medication-taking after stroke.

\begin{tabular}{|c|c|c|c|}
\hline Theme & Exemplar first order quote & Participant & Study \\
\hline \multicolumn{4}{|l|}{ Information work } \\
\hline \multirow[t]{3}{*}{ Positive examples } & $\begin{array}{l}\text { 'I think that taking the time to explain the } \\
\text { prescription to outpatients is really } \\
\text { important' }\end{array}$ & $\mathrm{HCP}$ & Bauler 2012 \\
\hline & $\begin{array}{l}\text { '...she (the stroke nurse) sent me out some } \\
\text { leaflets on things for HRT, and you know, } \\
\text { anything I needed to ask her, she was there } \\
\text { if I needed to phone her ... my own GP is } \\
\text { very good as well.' }\end{array}$ & Patient & $\begin{array}{l}\text { Chambers } \\
2011\end{array}$ \\
\hline & $\begin{array}{l}\text { '...the doctors explained to me why they } \\
\text { wanted me to take it, and they explained } \\
\text { the best time of day to take it. And I have } \\
\text { no reason to want to ignore their advice.' }\end{array}$ & Patient & $\begin{array}{l}\text { Chambers } \\
2011\end{array}$ \\
\hline \multirow[t]{4}{*}{$\begin{array}{l}\text { Lack of information } \\
\text { provision }\end{array}$} & $\begin{array}{l}\text { 'There's a lot of them, I don't know what } \\
\text { they're for. I've just always had them.' }\end{array}$ & Patient & $\begin{array}{l}\text { Chambers } \\
2011\end{array}$ \\
\hline & $\begin{array}{l}\text { 'No, I don't think we've got hardly any } \\
\text { information. We haven't ever really had a } \\
\text { lot of information about it have we? You } \\
\text { just sort of get on with it ... I mean perhaps } \\
\text { I haven't ever asked enough but ... I think } \\
\text { you should be, told in advance.' }\end{array}$ & Carer & Jamison 2016 \\
\hline & $\begin{array}{l}\text { 'I don't know why I take them, but it tells } \\
\text { you on each one, you know, what it's for ... } \\
\text { I wouldn't say I know what they're for.' }\end{array}$ & Patient & Jamison 2016 \\
\hline & $\begin{array}{l}\text { 'You'd get more information out of a leaflet } \\
\text { than you do with a person trying to tell } \\
\text { you.' }\end{array}$ & Patient & Souter 2014 \\
\hline \multirow[t]{4}{*}{$\begin{array}{l}\text { Need for ongoing } \\
\text { information }\end{array}$} & $\begin{array}{l}\text { 'There's one time it's such and such a brand } \\
\text { and the next it's another brand, so you get } \\
\text { used to seeing maybe a particular colour or } \\
\text { shape and then he changes it and you're, } \\
\text { 'Which one's which now?' }\end{array}$ & Patient & $\begin{array}{l}\text { Chambers } \\
2014\end{array}$ \\
\hline & $\begin{array}{l}\text { 'Well, if the chemist gives you another } \\
\text { make and the box changes as well... that to } \\
\text { me would confuse some people and it } \\
\text { makes you think a little bit harder.' }\end{array}$ & Patient & Chambers 2014 \\
\hline & $\begin{array}{l}\text { 'It was a smaller, a different-shaped tablet } \\
\text { and I thought, 'I wonder if it's the wrong } \\
\text { thing... I'll go to the chemist,' ... but no, he } \\
\text { said, 'It's just a different...' em, what would } \\
\text { you say, manufacturer?' }\end{array}$ & Patient & $\begin{array}{l}\text { Chambers } \\
2014\end{array}$ \\
\hline & $\begin{array}{l}\text { 'What I did notice was that the simvastatin } \\
\text { changed colour, changed from a pink tablet } \\
\text { to a white tablet, why that was I don't } \\
\text { know, but I'm assuming that it's still the } \\
\text { same stuff that's inside the capsule... I } \\
\text { suppose I'm doing in that case is trusting }\end{array}$ & Patient & $\begin{array}{l}\text { Chambers } \\
2014\end{array}$ \\
\hline
\end{tabular}


the pharmacist is doing their job properly...

\begin{tabular}{|c|c|c|c|}
\hline \multicolumn{4}{|l|}{ Healthcare Work } \\
\hline \multirow[t]{4}{*}{$\begin{array}{l}\text { Negative aspects of } \\
\text { healthcare work }\end{array}$} & $\begin{array}{l}\text { 'There is no way I'm going to take } \\
\text { warfarin... and have to go for blood tests... I } \\
\text { just hate them... suppose I had to go on a } \\
\text { Monday... well once it was over I would } \\
\text { start worrying for the next Monday.' }\end{array}$ & Patient & Souter 2014 \\
\hline & $\begin{array}{l}\text { 'I should go and see the doctor but making } \\
\text { an appointment is such a kerfuffle.' }\end{array}$ & Patient & Souter 2014 \\
\hline & $\begin{array}{l}\text { I should have really made an appointment } \\
\text { to go and see her (GP). I haven't seen her } \\
\text { since this happened } 14 \text { months ago.' }\end{array}$ & Patient & $\begin{array}{l}\text { Chambers } \\
2011\end{array}$ \\
\hline & $\begin{array}{l}\text { 'I have to take } 10 \text { a day now altogether but } \\
\text { I went up there [to the practice] to say can I } \\
\text { get off some of these tablets, and I come } \\
\text { back, and I was on an extra one, so I've not } \\
\text { been up since.' }\end{array}$ & Patient & Jamison 2016 \\
\hline $\begin{array}{l}\text { Patient-centred } \\
\text { healthcare work }\end{array}$ & $\begin{array}{l}\text { 'They changed his medication to cheaper } \\
\text { cholesterol and [he] was physically ill. He } \\
\text { couldn't cope on it at all, so he went back, } \\
\text { and the doctor said, "oh well it was just to } \\
\text { try" and they put him back on the others.' }\end{array}$ & Carer & Jamison 2016 \\
\hline \multicolumn{4}{|l|}{ Carer Work } \\
\hline \multirow[t]{4}{*}{$\begin{array}{l}\text { Organising the } \\
\text { medication }\end{array}$} & $\begin{array}{l}\text { 'People with family or with a good social } \\
\text { support have fewer difficulties in managing } \\
\text { their treatment.' }\end{array}$ & $\mathrm{HCP}$ & Bauler 2012 \\
\hline & $\begin{array}{l}\text { 'He's quite organised now. He made quite a } \\
\text { mess of it in the beginning, but we've got } \\
\text { him organised now.' }\end{array}$ & Carer & $\begin{array}{l}\text { Chambers } \\
2011\end{array}$ \\
\hline & $\begin{array}{l}\text { '...my sister, she's got everything well } \\
\text { organised (for me) on my wee meal table.' }\end{array}$ & Patient & $\begin{array}{l}\text { Chambers } \\
2011\end{array}$ \\
\hline & $\begin{array}{l}\text { 'My son was away. He always makes sure I } \\
\text { get my prescriptions and I forgot.' }\end{array}$ & Patient & $\begin{array}{l}\text { Chambers } \\
2011\end{array}$ \\
\hline \multirow[t]{2}{*}{$\begin{array}{l}\text { Overseeing } \\
\text { medication-taking }\end{array}$} & $\begin{array}{l}\text { 'My wife sorts it out and that's why I don't } \\
\text { know so much about it you see she [taps]. } \\
\text { She puts them there, I take them and that's } \\
\text { it.' }\end{array}$ & Patient & Jamison 2016 \\
\hline & $\begin{array}{l}\text { 'The warfarin one, my daughter always } \\
\text { makes sure I take it.' }\end{array}$ & Patient & Gallacher 2018 \\
\hline $\begin{array}{l}\text { Conflicts between } \\
\text { the patient and } \\
\text { carer }\end{array}$ & $\begin{array}{l}\text { 'What upsets me is that the doesn't like to } \\
\text { take medication or doesn't want to get the } \\
\text { prescriptions filled or he has one excuse } \\
\text { after another why he shouldn't take the } \\
\text { medicine.' }\end{array}$ & Carer & Bakas 2002 \\
\hline \multicolumn{4}{|l|}{ Emotional Work } \\
\hline \multirow[t]{2}{*}{ Perceived necessity } & $\begin{array}{l}\text { 'I have no choice; if I don't take the } \\
\text { medication, I will have a new stroke...' }\end{array}$ & Patient & Bauler 2012 \\
\hline & $\begin{array}{l}\text { 'I know I could die if I don't take my } \\
\text { medication.' }\end{array}$ & Patient & Bauler 2012 \\
\hline
\end{tabular}




\begin{tabular}{|c|c|c|c|}
\hline & $\begin{array}{l}\text { 'They have to understand that they could } \\
\text { have another stroke.' }\end{array}$ & $\mathrm{HCP}$ & Bauler 2012 \\
\hline & $\begin{array}{l}\text { 'No, I mean I just accept the fact that it's } \\
\text { got to be done and it's bad... I'd rather it } \\
\text { wasn't, but it's far better than the } \\
\text { alternative.' }\end{array}$ & Patient & $\begin{array}{l}\text { Chambers } \\
2011\end{array}$ \\
\hline & $\begin{array}{l}\text { 'I'm sort of, a little bit annoyed that l've } \\
\text { missed them but, no it doesn't worry me. It } \\
\text { would worry me if ... I missed them for } 3 \text { or } \\
4 \text { days but a day, no.' }\end{array}$ & Patient & Jamison 2016 \\
\hline \multirow{2}{*}{$\begin{array}{l}\text { Fear of having } \\
\text { another stroke }\end{array}$} & 'I could have another one and it scares me.' & Patient & Bauler 2012 \\
\hline & $\begin{array}{l}\text { 'We don't talk about it (recurrent stroke } \\
\text { risk), because they are already so anxious' }\end{array}$ & $\mathrm{HCP}$ & Bauler 2012 \\
\hline \multirow[t]{4}{*}{$\begin{array}{l}\text { Concerns about } \\
\text { taking medication }\end{array}$} & $\begin{array}{l}\text { 'It's a lot of tablets. At one point I just felt, I } \\
\text { felt as if I was dizzy with all these tablets.' }\end{array}$ & Patient & $\begin{array}{l}\text { Chambers } \\
2011\end{array}$ \\
\hline & $\begin{array}{l}\text { 'I told myself that things will no longer be } \\
\text { normal.'. }\end{array}$ & Patient & Bauler 2012 \\
\hline & $\begin{array}{l}\text { 'On a Sunday I don't take the water one } \\
\text { (diuretic) ... everybody looks at you if } \\
\text { you've got to waltz to the back of the } \\
\text { church to go to the loo.' }\end{array}$ & Patient & Souter 2014 \\
\hline & $\begin{array}{l}\text { 'Among the men you notice that they stop } \\
\text { taking their medications due to the fear of } \\
\text { getting sexual dysfunction...' }\end{array}$ & not stated & Nichols 2017 \\
\hline \multicolumn{4}{|l|}{ Practical Work } \\
\hline $\begin{array}{l}\text { Logistical and } \\
\text { technical work }\end{array}$ & $\begin{array}{l}\text { 'I only remember to take the others ... if I } \\
\text { take them out of the cupboard the night } \\
\text { before and leave them on the top. If I } \\
\text { didn't take them out, I would probably } \\
\text { forget ... because it isn't the first thing that } \\
\text { I think of ... when I first get up.' }\end{array}$ & Patient & Jamison 2016 \\
\hline \multirow[t]{3}{*}{$\begin{array}{l}\text { Physical sequelae of } \\
\text { stroke }\end{array}$} & $\begin{array}{l}\text { 'I have a problem swallowing... these are } \\
\text { quite big ones, these clopidogrel I bite into } \\
\text { them, I just resorted to... I bite into them } \\
\text { then I take the water or coffee, I manage to } \\
\text { swallow the bits...' }\end{array}$ & Patient & $\begin{array}{l}\text { Chambers } \\
2014\end{array}$ \\
\hline & $\begin{array}{l}\text { 'From a patient's perspective it's usually it's } \\
\text { just physically a lot of tablets you have to } \\
\text { swallow.' }\end{array}$ & $\mathrm{HCP}$ & Jamison 2016 \\
\hline & $\begin{array}{l}\text { 'Some of the, the pills are a hell of a } \\
\text { trouble, you know the bubble wrap, } \\
\text { flipping them out especially with my hands } \\
\text { not as strong as they should be.' }\end{array}$ & Patient & Jamison 2016 \\
\hline \multirow[t]{2}{*}{$\begin{array}{l}\text { Evolving and } \\
\text { maintaining a } \\
\text { medication routine }\end{array}$} & $\begin{array}{l}\text { 'I just do it routinely now. It's just part of } \\
\text { when you get up in the morning, what you } \\
\text { go through, you know. Have a shower, } \\
\text { brush your teeth...' }\end{array}$ & Patient & $\begin{array}{l}\text { Chambers } \\
2011\end{array}$ \\
\hline & $\begin{array}{l}\text { '...I forgot to take the pills with me (on a } \\
\text { weekend away) but I went down to the } \\
\text { chemist, and bought aspirins, but they are }\end{array}$ & Patient & $\begin{array}{l}\text { Chambers } \\
2011\end{array}$ \\
\hline
\end{tabular}




\begin{tabular}{|c|c|c|c|}
\hline & $\begin{array}{l}\text { small aspirins, so I just halved the big } \\
\text { aspirins...' }\end{array}$ & & \\
\hline \multirow[t]{4}{*}{$\begin{array}{l}\text { Modifying the } \\
\text { routine }\end{array}$} & $\begin{array}{l}\text { 'If I go out in the evening, I make sure I've } \\
\text { got my pills in my pill box, ready to be } \\
\text { taken.' }\end{array}$ & Patient & $\begin{array}{l}\text { Chambers } \\
2011\end{array}$ \\
\hline & $\begin{array}{l}\text { 'For example, the aspirin is (now) the same } \\
\text { colour as the lisinopril, and the lisinopril's } \\
\text { just a slightly bigger tablet. So, I've got to } \\
\text { dissolve the aspirin but keep the lisinopril } \\
\text { whole, so that's kind of... more an } \\
\text { inconvenience than anything else, you } \\
\text { know?' }\end{array}$ & Patient & $\begin{array}{l}\text { Chambers } \\
2014\end{array}$ \\
\hline & $\begin{array}{l}\text { 'There used to be paper at the back [of the } \\
\text { packet] and now I am sure some of them } \\
\text { are plasticky, and I'm sitting with a knife } \\
\text { trying to cut them [tablets] out.' }\end{array}$ & Patient & Souter 2014 \\
\hline & $\begin{array}{l}\text { 'Well they've just changed one of them, it's } \\
\text { the same stuff only... it's got no days on, } \\
\text { most of them have Monday, Tuesday, } \\
\text { Wednesday so if I go today and I see } \\
\text { Monday's there, I know l've forgotten one } \\
\text {...they've changed one of them and it's got } \\
\text { no bloody days on it at all.' }\end{array}$ & Patient & Gallacher 2018 \\
\hline \multirow[t]{3}{*}{ Affordability } & $\begin{array}{l}\text { 'Now it's like all these other pills and the } \\
\text { insulin and the blood sugar monitor. We } \\
\text { have to constantly keep buying all this } \\
\text { stuff.' }\end{array}$ & Carer & Bakas 2002 \\
\hline & $\begin{array}{l}\text { 'Some of the drugs are costly and it is not } \\
\text { easy to buy all of them.' }\end{array}$ & Not stated & Nichols 2017 \\
\hline & $\begin{array}{l}\text { 'Well, they just say (no), 'Well, it comes out } \\
\text { of our budget.' }\end{array}$ & Patient & $\begin{array}{l}\text { Chambers } \\
2014\end{array}$ \\
\hline \multicolumn{4}{|l|}{ Trust } \\
\hline \multirow[t]{4}{*}{$\begin{array}{l}\text { Imperceptible } \\
\text { benefit }\end{array}$} & $\begin{array}{l}\text { 'They do not feel sick, so they think that if } \\
\text { they do not take their medications they will } \\
\text { not be sick.' }\end{array}$ & $\mathrm{HCP}$ & Bauler 2012 \\
\hline & $\begin{array}{l}\text { 'Patients are tempted to stop taking their } \\
\text { medications as they no longer exhibit } \\
\text { clinical symptoms.' }\end{array}$ & $\mathrm{HCP}$ & Bauler 2012 \\
\hline & $\begin{array}{l}\text { 'I didn't think at first when I was taking } \\
\text { them that they were doing me any good. } \\
\text { And I did stop taking them.' }\end{array}$ & Patient & $\begin{array}{l}\text { Chambers } \\
2011\end{array}$ \\
\hline & $\begin{array}{l}\text { 'I've been taking all that for four years, I } \\
\text { might not need it.' }\end{array}$ & Patient & Gallacher 2018 \\
\hline $\begin{array}{l}\text { Trust in the efficacy } \\
\text { of specific } \\
\text { medication }\end{array}$ & $\begin{array}{l}\text { 'I think aspirins are good for you. That's the } \\
\text { only one I fancy. Well it thins the blood and } \\
\text { I think, well by thinning the blood it flows } \\
\text { better and that stops any clots, so I do like } \\
\text { to take it. I just don't see why I'm taking } \\
\text { other medication, I'm not fat or anything } \\
\text { like that. I don't get very high blood }\end{array}$ & Patient & Jamison 2016 \\
\hline
\end{tabular}




\begin{tabular}{|c|c|c|c|}
\hline & \multicolumn{3}{|l|}{$\begin{array}{l}\text { pressure, and well cholesterol, what is } \\
\text { cholesterol?' }\end{array}$} \\
\hline & $\begin{array}{l}\text { 'Well, if it was simvastatin I think that } \\
\text { would matter. The other ones I think you } \\
\text { could miss out a few without affecting my } \\
\text { blood pressure.' }\end{array}$ & Patient & $\begin{array}{l}\text { Chambers } \\
2011\end{array}$ \\
\hline & $\begin{array}{l}\text { 'Since taking all these medicines my blood } \\
\text { pressure has been coming down.' }\end{array}$ & Patient & Souter 2014 \\
\hline \multirow[t]{4}{*}{$\begin{array}{l}\text { Beliefs about } \\
\text { healthcare }\end{array}$} & $\begin{array}{l}\text { 'We have this belief that medicines do not } \\
\text { help.' }\end{array}$ & Not stated & Nichols 2017 \\
\hline & $\begin{array}{l}\text { 'I feel that whatever the doctor prescribes, } \\
\text { they know what they are doing, and talking } \\
\text { about... I've got trust in the doctor.' }\end{array}$ & Patient & $\begin{array}{l}\text { Chambers } \\
2011\end{array}$ \\
\hline & $\begin{array}{l}\text { 'So, if the doctor says take ten pills a day, } \\
\text { I'll, I'll do it ... he makes the decision and } \\
\text { erm he, he's the boss man as you might } \\
\text { say, who knows what he's up to.' }\end{array}$ & Patient & Jamison 2016 \\
\hline & $\begin{array}{l}\text { 'He's the pharmacist and he deals with } \\
\text { drugs. He's bound to know what's what. He } \\
\text { didn't pass his qualifications just to pop out } \\
\text { some pills and say there you are.' }\end{array}$ & Patient & Souter 2014 \\
\hline
\end{tabular}

